\title{
Integrating Experiential Learning in an Introductory Financial Accounting Course to Enhance Learning: The FIFA Approach
}

\author{
Najihah Marha Yaacob ${ }^{1, *}$, Najib Majdi Yaacob ${ }^{2}$, Roziani Ali ${ }^{1}$ \\ ${ }^{1}$ Faculty of Accountancy, Universiti Teknologi MARA Cawangan Terengganu, Malaysia \\ ${ }^{2}$ Unit of Biostatistics and Research Methodology, School of Medical Sciences, Universiti Sains Malaysia, Malaysia
}

Received July 15, 2020; Revised September 8, 2020; Accepted November 19, 2020

\section{Cite This Paper in the following Citation Styles}

(a): [1] Najihah Marha Yaacob, Najib Majdi Yaacob, Roziani Ali, "Integrating Experiential Learning in an Introductory Financial Accounting Course to Enhance Learning: The FIFA Approach," Universal Journal of Educational Research, Vol. 8, No. 12A, pp. 7246 - 7257, 2020. DOI: 10.13189/ujer.2020.082507.

(b): Najihah Marha Yaacob, Najib Majdi Yaacob, Roziani Ali (2020). Integrating Experiential Learning in an Introductory Financial Accounting Course to Enhance Learning: The FIFA Approach. Universal Journal of Educational Research, 8(12A), 7246 - 7257. DOI: 10.13189/ujer.2020.082507.

Copyright $₫ 2020$ by authors, all rights reserved. Authors agree that this article remains permanently open access under the terms of the Creative Commons Attribution License 4.0 International License

\begin{abstract}
The Fieldwork Introductory Financial Accounting [FIFA] approach was introduced to resolve the problem of lack of understanding of basic financial accounting among accounting students with no background in accounting for the Financial Accounting 1 (FAR 110) course. The FIFA approach stemmed from the initiative of the teaching lecturers to enhance students' understanding of the most significant and elementary accounting knowledge: (i) identification and classification of accounting elements (assets, liabilities, revenues, expenses \& equities), and (ii) sources of documents. The main purpose of this paper is to determine the effectiveness of the FIFA approach in enhancing students' understanding throughout an introductory financial accounting course. A total of 79 students participated in this study, and were divided into 2 groups; the treatment group and the control group. The experimental design using a non-randomised control group pre-test-post-test design was utilised. This study revealed that the FIFA approach significantly enhanced the students' understanding of the most significant elementary accounting knowledge, which comprises identification and classification of accounting elements and sources of documents. The findings are expected to benefit higher-education institutions, particularly accounting academics and curriculum coordinators when performing Accounting-curriculum revision so as to embed the FIFA approach in their introductory accounting courses. Moreover, the results of
\end{abstract}

this study are expected to encourage countless educators to incorporate more learning activities associated with the active-learning approach and pedagogies beyond the four walls, which could boost students' knowledge and skills. The findings of this study also provide evidence on how real-world exposure is vital in order to facilitate accounting knowledge and understanding.

Keywords Accounting, Financial Accounting, Fieldwork, Experiential Learning

\section{Introduction}

Issues pertaining to students' lack of understanding of accounting elements, their classification, and difficulty in visualising sources of documents have been discovered in the Introductory Financial Accounting Course (FAR110), particularly amongst students with no background in Accounting. It was revealed that about one third (1/3) of the new accounting students did not have any accounting background, while the remaining two thirds (2/3) of the students had secured some accounting knowledge during their last two-years of secondary education. Compelled by the fact that the first month of the first semester is the most critical period for students to understand and catch up on the basic knowledge of financial accounting, i.e. 
accounting elements and sources of documents, the abovementioned former group of students struggled to compete with the latter group, in which the students had an accounting background. In a few severe cases, some students expressed frustration at being left behind, leaving them feeling demotivated.

One of the responses received from the new students without any accounting background is as follows:

"Once, I felt that I wanted to quit university and sought to join the pre-university programme since I'd already missed my chance to get into matriculation. Unfortunately, I also missed the date of admission for the pre-university programme. So, I had no chance but to pursue my studies in this course. One of the reasons that pushed me to quit university is that I was awfully depressed because of my friends, especially in the first month. There was a time when I couldn't answer even a single question asked by a lecturer in class. But when it was my friend's turn, she was able to answer it very well. It made me feel very shy and intimidated to participate in question-and-answer sessions (Q\&A) in class whenever our lecturer asked. Besides, all of my friends' scores in quizzes and tests have been higher than mine on average. Plus, teaching and learning in English has made me feel even more inferior and down. When the lecturer was explaining the course syllabus with some never-heard-of jargon and Accounting terms such as 'journals' and 'ledgers', I wondered how, by any means, I could manoeuvre and survive in this full-of-thorns-and-spikes journey of learning the course with zero-background knowledge. Could I be able to compete with my knowledgeable, all-knowing, omniscient friends?”

New students like the one who gave the abovementioned feedback were therefore the main reason why the Fieldwork Introductory Financial Accounting [FIFA] approach was introduced to resolve the problem of the lack of understanding of first-semester accounting students with no accounting background who is taking the Introductory Financial Accounting FAR110 Course. This approach requires participants to conduct fieldwork to experience their chosen business. This sort of fundamental knowledge is vital for the students' continuous assessment, particularly in the accounting simulation project and mid-semester exam and, most importantly, for their survival throughout the accounting programme. At the end, this approach would springboard their knowledge and interest to greater heights.

In Malaysia, the importance of research-based education has been highlighted in the requirement of the Code of Practice Programme Accreditation (COPPA) Standard. According to Area 5 (Section 5.2.2) of the COPPA 2nd Edition [1], it is pointed out that "the interaction between research and learning must be reflected in the curriculum, influence current teaching, and encourage and prepare students for engagement in research, scholarship, and development”. Hence, higher-education institutions (HEIs) are obliged to encourage interactions between research and learning as an effective avenue to inculcate research culture among students. In addition, there must be a link between the HEI policy on research and teaching-and-learning activities in the academic department.

With regard to the implementation of the FIFA approach, the concern is whether this approach is really effective in enhancing the understanding of Financial Accounting 1 (FAR110) Course for Diploma in Accountancy (DIA) students. Thus, the objective of this study is to determine the effect of the FIFA approach towards the understanding of the basic identification and classification of accounting elements and various sources of documents.

The paper is organised as follows. Firstly, the literature review is discoursed to provide a clearer picture of the term 'experiential learning,' and to highlight several studies to prove the significance of this approach with different methodologies. Next, the research method is explained, which is then followed by the findings and discussions, and ends with the conclusion and recommendations.

\section{Literature Review}

The most notable philosopher on learning through experience is John Dewey, where in the 19th century his work was recognised, adapted, enriched, and debated among scholars. There are numerous definitions and scopes of experiential learning, and its substance was progressively developed over time. McKeachie [2] has defined experiential learning as "a broad spectrum of educational experiences, such as community service, fieldwork, sensitivity training groups, workshops, internships, cooperative education involving work in business and industry, and undergraduate participation in faculty research,” (p. 246). According to Beard and Wilson [3], experiential learning can be referred to as "the sense-making process of active engagement between the inner world of the person and the outer world of the environment” (p. 19). In this study, the fieldwork approach is a sub-domain of experiential learning that integrates field research into an interesting learning experience and knowledge. There are two significant aspects of experiential learning, which are associated with intermingling between experience and reflection [4]. Experiential learning through fieldwork requires participants to experience a knowledge-gaining process beyond a classroom-learning process. This approach moves away from brick-and-wall, chalk-and-talk, and face-to-face learning to a broader context of learning process. The fieldwork approach combines classroom teaching with applied fieldwork to build a close nexus between teaching and research [5].

Past studies have proven many success stories of experiential learning in higher-education institutions across boundaries [see for instance 6,7], utilising various experimental-learning tools or instruments as measurements, such as instructional strategies [8], a 
pre-test-post-test design on various learning [9], structured interview sessions [10], community volunteering programmes [11], fieldwork [12], internships [13], undergraduate research [7], and accounting software utilisation [14][15]. The measurements of experiential-learning success are student outcomes via their performance in exams [8][11][13], while some studies have used soft-skills indicators [9][10] [13].

The Experiential Learning Theory (ELT) by David Kolb was utilised by Jensen [8] to investigate whether or not the first-semester students' performance in the college accounting course (measured through four exams) was significantly greater than the performance of students taught in a traditional lecture-style/lecturer-oriented format. The researchers divided the students into two (2) groups; a control group and a treatment group. The control group had undergone a normal lecture-type environment, while the treatment group was required to undergo the instructional strategies designed to meet the four learning phases as suggested by the ELT (concrete experience, reflective observation, abstract conceptualisation, and active experimentation). The findings discovered that, for all four exams, there was a significant difference in the mean scores of the treatment and control groups. Walker [11] explored whether or not experiential learning contributed significantly to the completion and success of the Accounting 224 Business Taxation Course by community-college students. The study employed a mixed-method approach, and gathered quantitative and qualitative data by using seventy-five (75) samples from respondents involved in the Spring 2018 Volunteer Income Tax Assistance (VITA) programme, with another 88 respondents that had not participated in the programme. The quantitative results revealed that the experiential-learning participants were able to complete the course at a higher passing rate than the non-participants. Thus, the researchers concluded that experiential learning has a positive, significant relationship with the completion rates of the accounting students and their end-of-course grades. The qualitative findings from the perspective of the participating students discovered four (4) experiential learning themes, namely: "applying classroom knowledge in a real-world environment, assisting the community, gaining self-confidence and adding value to education and career” (pg 82). Furthermore, the community perspectives disclosed two (2) themes: "serving the community and student engagement” (pg 83).

Martin [13] conducted a study to determine a relationship between self-efficacy and experiential learning among low American College Testing (ACT) students with a composite score of 20 or less. The researchers conducted a qualitative study by using semi-structured interviews, and the data was analysed by using Nvivo11 software to determine the conceptual/theme content analysis. The study revealed that experiential learning and an internship experience are acknowledged as contributing factors to the students' academic success. Moreover, the lateral aspects of experiential learning, namely social skills and social interactions are enhanced through this process.

Cornell et al. [10] utilized structured interviews as an experiential learning mechanism to evaluate the effectiveness of such approach in an introductory accounting course, and to determine whether the approach could boost students' understanding. In the study, the sample consisted of 85 undergraduate students and 32 Master of Business Administration (MBA) students. The students (participants) were required to identify the subject, conduct the structured interview, to record the response and to document the reflections from the interview. Once students were done with the interview mechanism, they had to answer three open-ended questions. The findings showed that the participants concurred that they understood the real-world applications of the accounting concepts better; the open-ended questions enhanced their interest in accounting, and they appreciated the interview approach more as compared to the traditional classroom. Consequently, their soft skills were enhanced as well as their confidence levels. In conjunction, Ali, Wan Mohd Nori and Baharuddin [16] employed open ended questions to collect feedback of the students' perceptions towards the Accounting Experiential Learning Firm (AELF) program. The respondents consist of 20 students from the first and final semester of the Diploma in Accountancy program that had joined the AELF program. The results revealed that all participants (20 students) answered YES on the impact of the program on boosting their interest in the accounting profession, improving their understanding of accounting subjects, and augmenting their soft skills.

In gauging the impact of software utilisation among undergraduate students of Bachelor of Commerce (BCom) with accounting as a major, Boulianne [14] segregated the students into three (3) groups: Group 1 completed the manual accounting case, Group 2 completed the accounting case using software, Group 3 using both manually and then using software to complete the accounting case. Using 1,053 samples over a 5-year period (2006 to 2010), this study revealed that the students that utilised both the manual accounting case accompanied by the accounting software were the best approach to knowledge acquisition. Moreover, students who utilised the accounting software to complete the accounting case outperformed students who manually completed the case.

The discussed past studies accentuated the sample from the undergraduate students. At the post-graduate level, Juergens [17] examined the relationship between three (3) independent variables, namely perceived utility, motivation to transfer, and performance self-efficacy with transfer of learning (experiential learning). The researchers also control several control variables such as experience before entering the MBA program, experience after completing the MBA program, length of time in current position and type of experiential learning opportunity 
participated in. The questionnaires were distributed to 205 full-time MBA graduates over a four year (2008 - 2011) period, in which the MBA graduates engaged in experiential learning opportunities, both informal (activities) and formal (classes). The study revealed that two (2) factors significantly affect experiential learning, namely perceived utility and motivation to transfer.

The above discussions have demonstrated that researchers have utilised different instruments to gauge the effectiveness of experiential learning. In deciding whether or not the success of experiential learning depends on the types of instruments used or the period of engagement, Coker et al. [7] compared students' results (based on academic transcripts) with experiential-learning depth (time spent) and breadth (types of experiences undergraduate research, internships, studying abroad, services, and leadership experiences). The study used a pool of data from five (5) batches of graduating students for five (5) years. The findings revealed that both experiential-learning depth and breadth have a positive relationship with the students' performances. Nevertheless, each aspect has a specific advantage, whereby depth impacts higher-order thinking skills, while breadth has the greatest impact on cognitive gains.

Based on the literature discussed above, this study has hypothesised that:

Ha1: Students without an accounting background have lower understanding of the basic identification and classification of accounting elements and various sources of documents compared to those with an accounting background.

Ha2: The FIFA approach is effective for increasing students' understanding of the basic identification and classification of accounting elements and various sources of documents.

\section{Research Method}

The sample of this study consists of students taking the introductory financial accounting course during the September 2019 - January 2020 Semester. A total of seventy-nine (79) students participated in this study, and were divided into two groups: the treatment group and the control group. The participants, who either had or didn't have prior accounting knowledge, were assigned based on the accounting knowledge acquired during secondary education. This study used experimental design by using a non-randomised control group pre-test-post-test design in which the measurements were taken both before and after the treatment. Preceding the fieldwork, both groups were required to answer a set of pre-test questions designed to cover the basic accounting aspects (Appendix 1). Similarly, both groups have also been required to answer post-test questions after successfully completing the fieldwork.

The questionnaire was designed as a self-administered questionnaire, and consisted of two sections; 22 items in the first section, and eight items in the second section. In the first section, the students were instructed to classify the 22 accounting items into assets, liability, revenue, expenses, or capital based on a description of the items. In the second section, the students were instructed to classify the source of documents based on eight document images (invoice, receipt, cheque, payment voucher, bank slip, bill, bank statement and cash book). For each item, one would be given for each correct answer and zero score incorrect or blank answers. The total score was calculated by adding the sum of all 30 items, with zero as the minimum possible total score and 30 as the maximum possible score. Higher scores indicated better knowledge among the students.

The SPSS Version 24 was used for statistical analysis. Data exploration and cleaning was conducted to ensure that there was no error in data entry prior to data analysis. The distribution of numerical variables was evaluated by assessing skewness values, kurtosis values, test of normality (Kolmogorov-Smirnov and Shapiro Wilk test), and histogram with overlaid normal curve. All the numerical variables were described as their mean and standard deviation (SD) if they are normally distributed. However, if they are abnormally distributed, then their median and interquartile range (IQR) would be used instead.

The baseline characteristics of the research participants in both the intervention and control groups were compared by using the Independent Sample T-test (or Mann Whitney U-test if normality assumption is violated) and the Chi Square Test (or Fisher Exact Test if any assumptions for the Chi Square Test were violated). To determine the effect of the FIFA Approach, changes in understanding the scores within both groups were evaluated by using the Paired-sample T-test (or the Wilcoxon Sign Rank Test if any assumptions for the Paired T-test were violated). The difference in the post-intervention understanding scores between the intervention and control groups was evaluated by using the Paired Sample T-test (or the Mann-Whitney U-test). A P-value of less than 0.05 is considered as statistically significant in all the statistical analyses conducted.

\section{Results}

Table 1 shows the characteristics of the participants according to the groups; the group with accounting background comprises thirty-seven (37) females and fourteen (14) males, while the group without any accounting background consists of twenty-one (21) females and seven (7) males as the respondents. Comparison of sex indicates no significant difference between both groups $\left[\chi^{2}(1)=0.06, \mathrm{P}=0.814\right]$. A majority of the participants for both groups (with and without accounting background) earned their secondary education 
in national secondary schools (64.7\%; 67.9\%). Fisher exact text indicates that there is no significant difference in types of schools attended by both groups $(\mathrm{P}=0.287)$. On average, the participants both with and without accounting background obtained 4.84 A's and 4.14 A's respectively in the Sijil Pelajaran Malaysia (SPM) examination. The independent sample t-test indicated no significant difference in the students' achievement at SPM level between both groups [ $\mathrm{t}(77)=1.94, \mathrm{P}=0.057]$.

Table 2 and 3 shows the item level analysis of the 30 questionnaire items, at baseline (before) and after intervention among the students with accounting background and without accounting background. Among students with an accounting background, improvement in the correct answers for most of the items was observed with statistically significant improvement for item 19 . The improvement in knowledge was more prominent among students without an accounting background, where there was statistically significant improvement for items 6,12 , 13, 15, 18, 20, 23, 24, 28, 29 and 30.

Table 1. Characteristics of the participants according to the groups $(\mathrm{n}=79)$

\begin{tabular}{|c|c|c|}
\hline Variable & $\begin{array}{c}\text { With Accounting } \\
\text { Background }(n=51)\end{array}$ & $\begin{array}{l}\text { Without Accounting } \\
\text { Background }(n=28)\end{array}$ \\
\hline $\begin{array}{c}\text { Sex } \\
\text { - Female } \\
\text { - Male }\end{array}$ & $\begin{array}{l}37(72.5) \\
14(27.5)\end{array}$ & $\begin{array}{c}21(75.0) \\
7(25.0)\end{array}$ \\
\hline $\begin{array}{l}\text { Type of Secondary } \\
\text { School Attended } \\
\text { - National } \\
\text { Secondary School } \\
\text { - Science Schools } \\
\text { - MARA Junior } \\
\text { - Science College } \\
\text { - Others }\end{array}$ & $\begin{array}{c}4(7.8) \\
3(5.9) \\
11(21.6)\end{array}$ & $\begin{array}{l}19(67.9) \\
4(14.3) \\
3(10.7) \\
2(7.1)\end{array}$ \\
\hline $\begin{array}{c}\text { Number of As } \\
\text { obtained in SPM; } \\
\text { mean (SD) }\end{array}$ & 4.84 (1.63) & 4.14 (1.35) \\
\hline
\end{tabular}

Table 2. Number and percentage of correct answer for each questionnaire items among students with accounting background ( $\mathrm{n}=51)$

\begin{tabular}{|c|c|c|c|c|}
\hline Item Number & Correct Answer & Pre & Post & p-value \\
\hline Q1 & Capital & 39/51 (76.5\%) & 41/51 (80.4\%) & 0.791 \\
\hline Q2 & Revenue & 42/51 (82.4\%) & 42/51 (82.4\%) & $>0.999$ \\
\hline Q3 & Asset & 48/51 (94.1\%) & 50/51 (98\%) & 0.500 \\
\hline Q4 & Asset & $11 / 51(21.6 \%)$ & 17/51 (33.3\%) & 0.109 \\
\hline Q5 & Expense & 49/51 (96.1\%) & 50/51 (98\%) & $>0.999$ \\
\hline Q6 & Asset & 47/51 (92.2\%) & 50/51 (98\%) & 0.375 \\
\hline Q7 & Liability & 46/51 (90.2\%) & 49/51 (96.1\%) & 0.375 \\
\hline Q8 & Asset & 43/51 (84.3\%) & 44/51 (86.3\%) & $>0.999$ \\
\hline Q9 & Expense & $33 / 51$ (64.7\%) & $38 / 51$ (74.5\%) & 0.302 \\
\hline Q10 & Expense & 40/51 (78.4\%) & 42/51 (82.4\%) & 0.727 \\
\hline Q11 & Liability & 46/51 (90.2\%) & 46/51 (90.2\%) & $>0.999$ \\
\hline Q12 & Asset & 50/51 (98\%) & $51 / 51$ (100\%) & $>0.999$ \\
\hline Q13 & Asset & 47/51 (92.2\%) & 47/51 (92.2\%) & $>0.999$ \\
\hline Q14 & Asset & 45/51 (88.2\%) & 50/51 (98\%) & 0.125 \\
\hline Q15 & Expense & 45/51 (88.2\%) & 48/51 (94.1\%) & 0.375 \\
\hline Q16 & Asset & 50/51 (98\%) & 50/51 (98\%) & $>0.999$ \\
\hline Q17 & Expense & 45/51 (88.2\%) & 50/51 (98\%) & 0.125 \\
\hline Q18 & Asset & $35 / 51(68.6 \%)$ & $42 / 51(82.4 \%)$ & 0.092 \\
\hline Q19 & Asset & 8/51 (15.7\%) & 19/51 (37.3\%) & 0.003 \\
\hline Q20 & Expense & 48/51 (94.1\%) & $43 / 51(84.3 \%)$ & 0.180 \\
\hline Q21 & Revenue & 40/51 (78.4\%) & 40/51 (78.4\%) & $>0.999$ \\
\hline Q22 & Asset & 50/51 (98\%) & $51 / 51(100 \%)$ & $>0.999$ \\
\hline Q23 & Invoice & 23/51 (45.1\%) & $21 / 51(41.2 \%)$ & 0.727 \\
\hline Q24 & Receipt & 29/51 (56.9\%) & $30 / 51$ (58.8\%) & $>0.999$ \\
\hline Q25 & Cheque & 44/51 (86.3\%) & 48/51 (94.1\%) & 0.125 \\
\hline Q26 & Payment voucher & $21 / 51(41.2 \%)$ & 25/51 (49\%) & 0.503 \\
\hline Q27 & Bank slip & 25/51 (49\%) & $21 / 51(41.2 \%)$ & 0.388 \\
\hline Q28 & Bill & 13/51 (25.5\%) & 17/51 (33.3\%) & 0.344 \\
\hline Q29 & Bank statement & 35/51 (68.6\%) & $37 / 51(72.5 \%)$ & 0.774 \\
\hline Q30 & Cash book & 47/51 (92.2\%) & 49/51 (96.1\%) & 0.625 \\
\hline
\end{tabular}

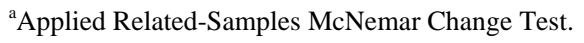


Table 3. Number and percentage of correct answer for each questionnaire items among students without accounting background ( $\mathrm{n}=28$ )

\begin{tabular}{|c|c|c|c|c|}
\hline /Item Number & Correct Answer & Pre & Post & $p$-value ${ }^{a}$ \\
\hline Q1 & Capital & 17/28 (60.7\%) & 21/28 (75\%) & 0.289 \\
\hline Q2 & Revenue & $18 / 28$ (64.3\%) & 23/28 (82.1\%) & 0.180 \\
\hline Q3 & Asset & 27/28 (96.4\%) & 28/28 (100\%) & $>0.999$ \\
\hline Q4 & Asset & 7/28 (25\%) & 6/28 (21.4\%) & $>0.999$ \\
\hline Q5 & Expense & $22 / 28$ (78.6\%) & 25/28 (89.3\%) & 0.375 \\
\hline Q6 & Asset & 14/28 (50\%) & 25/28 (89.3\%) & 0.001 \\
\hline Q7 & Liability & 23/28 (82.1\%) & 27/28 (96.4\%) & 0.219 \\
\hline Q8 & Asset & $13 / 28(46.4 \%)$ & $16 / 28(57.1 \%)$ & 0.581 \\
\hline Q9 & Expense & 8/28 (28.6\%) & 15/28 (53.6\%) & 0.118 \\
\hline Q10 & Expense & $22 / 28$ (78.6\%) & 27/28 (96.4\%) & 0.063 \\
\hline Q11 & Liability & 21/28 (75\%) & 22/28 (78.6\%) & $>0.999$ \\
\hline Q12 & Asset & 19/28 (67.9\%) & 27/28 (96.4\%) & 0.008 \\
\hline Q13 & Asset & $16 / 28(57.1 \%)$ & 25/28 (89.3\%) & 0.004 \\
\hline Q14 & Asset & 15/28 (53.6\%) & 28/28 (100\%) & $<0.001$ \\
\hline Q15 & Expense & $15 / 28$ (53.6\%) & 23/28 (82.1\%) & 0.039 \\
\hline Q16 & Asset & 27/28 (96.4\%) & 28/28 (100\%) & $>0.999$ \\
\hline Q17 & Expense & 20/28 (71.4\%) & 23/28 (82.1\%) & 0.508 \\
\hline Q18 & Asset & $13 / 28$ (46.4\%) & 26/28 (92.9\%) & 0.001 \\
\hline Q19 & Asset & 5/28 (17.9\%) & 11/28 (39.3\%) & 0.108 \\
\hline Q20 & Expense & $12 / 28$ (42.9\%) & 19/28 (67.9\%) & 0.016 \\
\hline Q21 & Revenue & 22/28 (78.6\%) & 25/28 (89.3\%) & 0.375 \\
\hline Q22 & Asset & 24/28 (85.7\%) & 28/28 (100\%) & 0.125 \\
\hline Q23 & Invoice & 5/28 (17.9\%) & 15/28 (53.6\%) & 0.006 \\
\hline Q24 & Receipt & 3/28 (10.7\%) & $11 / 28$ (39.3\%) & 0.021 \\
\hline Q25 & Cheque & 6/28 (21.4\%) & 23/28 (82.1\%) & $<0.001$ \\
\hline Q26 & Payment voucher & 3/28 (10.7\%) & 8/28 (28.6\%) & 0.125 \\
\hline Q27 & Bank slip & 6/28 (21.4\%) & 9/28 (32.1\%) & 0.508 \\
\hline Q28 & Bill & 4/28 (14.3\%) & 15/28 (53.6\%) & 0.001 \\
\hline Q29 & Bank statement & 5/28 (17.9\%) & 14/28 (50\%) & 0.012 \\
\hline Q30 & Cash book & 7/28 (25\%) & 17/28 (60.7\%) & 0.021 \\
\hline
\end{tabular}

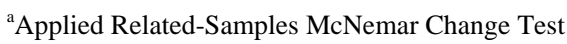

Table 4 shows the changes in the total scores before and after intervention within each group. At the baseline (pre-intervention), the test scores are statistically and significantly different between the participants either with or without accounting background. It was observed that the participants with an accounting background have significantly higher test scores (mean $=22.43, \mathrm{SD}=3.09$ ) compared to those without an accounting background (mean=14.96, $\mathrm{SD}=5.90)(\mathrm{P}<0.001)$.

Similarly, there is a statistically significant difference in the test scores between the participants with an accounting background and those without an accounting background. It was found that those with an accounting background had higher test scores (mean=23.67, SD=2.53) compared to those without an accounting background. The difference is statistically significant with $\mathrm{P}=0.006$.

Within the group of participants with an accounting background, there is an average of 1.25 unit increment in the test scores from pre-intervention (mean $=22.43$, $\mathrm{SD}=23.67)$ to post-intervention (mean=23.67, $\mathrm{SD}=2.53$ ), and it is statistically significant (mean difference: 1.25 , 95\% CI: 0.57, 1.94; $\mathrm{P}=0.001$ ). Within the group of the participants without an accounting background, considerably more sizeable changes occurred, in which there was an average increment of 6.82 units from pre-intervention (mean=14.96, $\quad \mathrm{SD}=3.37) \quad$ to post-intervention (mean=21.79, $\mathrm{SD}=3.37$ ). Statistically, it is significant (mean difference: 6.82; 95\% CI: 4.49, 9.16; $\mathrm{P}<0.001)$. 
Table 4. Changes in the test scores before and after intervention within each group $(n=79)$

\begin{tabular}{|c|c|c|c|}
\hline Time & $\begin{array}{c}\text { With } \\
\text { Accounting } \\
\text { Background } \\
(n=51)\end{array}$ & $\begin{array}{c}\text { Without } \\
\text { Accounting } \\
\text { Background } \\
(n=28)\end{array}$ & $\begin{array}{c}\text { Between-Group } \\
\text { Difference }^{\mathrm{b}}\end{array}$ \\
\hline Pre-intervention & 2243 (3.09) & $14.96(5.90)$ & $\begin{array}{c}\mathrm{t}(35.32)=7.39^{\mathrm{c}} \\
\mathrm{P}<0.001\end{array}$ \\
\hline Post-intervention & 23.67 (2.53) & 21.79 (3.37) & $\begin{array}{c}t(77)=2.84^{\mathrm{d}} \\
\mathrm{P}=0.006\end{array}$ \\
\hline $\begin{array}{l}\text { Within-group } \\
\text { changes }^{\mathrm{a}}\end{array}$ & $\begin{array}{c}t(50)=3.69 \\
P=0.001\end{array}$ & $\begin{array}{c}t(27)=5.99 \\
P<0.001\end{array}$ & \\
\hline
\end{tabular}

\section{Discussions and Conclusion}

The idea to innovate the FIFA approach was initiated following the issues or problems of apprehension in the teaching and learning of the Financial Accounting 1 (FAR110) Course for Diploma in Accountancy (DIA) students as mentioned by one of the participants with an accounting background as follows: "When I knew that most of my classmates had basic knowledge about Accounting, I became so weak and lost my confidence. This was due to my thought that I was not able to compete with them to get a good result for this subject. Moreover, I knew that the level of my ability to be adept in academic was not so high". The main objective of this study is to determine the effectiveness of the FIFA approach in improving students' understanding on accounting elements and accounting classification. This approach was introduced to assist the students to understand the ultimate basic accounting, which refers to accounting elements, namely assets, liabilities, equities, revenues and expenses, and sources of documents better.

This consequently helped them to perform better in the mid-semester test and accounting simulation project. There are two (2) hypotheses developed, as follows:

Ha1: Those without an accounting background have lower understanding of the basic identification and classification of accounting elements and various sources of documents compared to those with an accounting background.

Ha2: The FIFA approach is effective for increasing student's understanding of the basic identification and classification of accounting elements and various sources of documents.

The data have been obtained from a total of seventy-nine (79) participants who were divided into two (2) groups: twenty-eight (28) participants in the treatment group, and fifty-one (51) participants in the control group. The study used experimental design by using the non-randomised control group pre-test-post-test design, in which the measurements had been taken both before and after the treatment. The participants were assigned based on accounting knowledge acquired during secondary education (without and with accounting background).

The results have revealed that all the hypotheses are supported, which indicate that those students without an accounting background have significantly lower knowledge on the basic identification and classification of accounting elements and various sources of documents compared to those with an accounting background. In the interim, the pre-test-post-test results also revealed that the FIFA approach has significantly enhanced students' understanding about the most elementary accounting knowledge. The result is consistent with the findings of a study conducted by Cornell et al. [10], who have reported that experiential learning through structured interviews is effective in understanding accounting concepts. Meanwhile, Walker [11] has also found that the exposure to experiential learning has significantly increased the end-of-course grades and completion rates of Accounting 224 Business Taxation Course for accounting students. Similarly, Martin [13] has discovered that the academic success of students is determined by experiential learning and internship experiences. Besides, Boulianne [14] has also revealed that a treatment group that has utilised both manual and software to complete an accounting case has performed better.

The results of this study provides empirical evidence that the students who have been exposed to learning through experience, particularly their involvement in fieldwork or site visit, have significantly improved their underpinning of accounting knowledge. As a consequence, to certain extent, their knowledge is at par with the students that have learned Accounting in secondary school for two (2) years.

The data used in this study were collected from only one university in Malaysia at that particular point of time, thus, the generalisation of the results to other universities should be extra carefully made. The findings are expected to benefit higher-education institutions, particularly accounting academics and curriculum coordinators when performing Accounting-curriculum revision to embed the FIFA approach in introductory accounting courses. Moreover, the findings of this study would be expected to encourage countless educators to incorporate more learning activities associated to the active-learning approach and pedagogies beyond the four walls, which could boost students' knowledge and skills. 


\section{Appendix 1}

\section{EXPERIMENTAL DESIGN - A NONRANDOMIZED CONTROL GROUP PRETEST-POSTTEST}

\section{FIELDWORK INTRODUCTORY FINANCIAL ACCOUNTING [FIFA] APPROACH}

\section{SECTION A}

Ilman Enterprise is a retailer and has the following balances in his accounting books as at 31 August 2019. You are required to classify the following accounting items into Assets, Liability, Revenues, Expenses and Capital.

\begin{tabular}{|l|c|c|}
\hline No & Description & Classification \\
\hline 1. & Cash contribution by the owner & \\
\hline 2. & Sales & \\
\hline 3. & Land & \\
\hline 4. & Investment in Unit Trust & \\
\hline 5. & Advertising & \\
\hline 6. & Cash at bank & \\
\hline 7. & Bank loan & \\
\hline 8. & Accounts receivable & \\
\hline 9. & Carriage inwards & \\
\hline 10. & Purchases & \\
\hline 11. & Accounts payable & \\
\hline 12. & Inventories & \\
\hline 13. & Cash in hand & \\
\hline 14. & Building & \\
\hline 15. & Salaries & \\
\hline 16. & Van & \\
\hline 17. & Telephone & \\
\hline 18. & Fixtures \& fittings & \\
\hline 19. & Patent \& trademarks & \\
\hline 20. & Insurance & \\
\hline 21. & Dividend received & Lorries \\
\hline 22. & SCORE & \\
\hline & & \\
\hline
\end{tabular}

\section{SECTION B}

Identify the following source documents

\begin{tabular}{|c|c|c|c|c|c|c|}
\hline \multicolumn{6}{|c|}{ Source Documents } & $\begin{array}{l}\text { Name of } \\
\text { Document }\end{array}$ \\
\hline \multirow{7}{*}{1} & \multicolumn{5}{|c|}{ 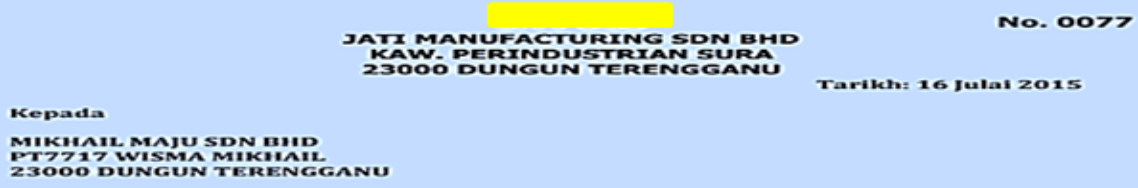 } & \\
\hline & Bil & Butir & Kuantiti & Harga seunit & $\begin{array}{l}\text { Jumlah } \\
\text { (RM) }\end{array}$ & \\
\hline & 1 & Rak Pameran & 5 & 500.00 & 2500.00 & \\
\hline & 2 & Meja Pejabat & 10 & 800.00 & 8000.00 & \\
\hline & & & & Jumlah & 10500.00 & \\
\hline & \multicolumn{5}{|c|}{ (Ringgit Malaysia: Sepuluh Ribu Lima Ratus Sahaja) } & \\
\hline & \multicolumn{4}{|c|}{ Penerima } & engurus & \\
\hline
\end{tabular}




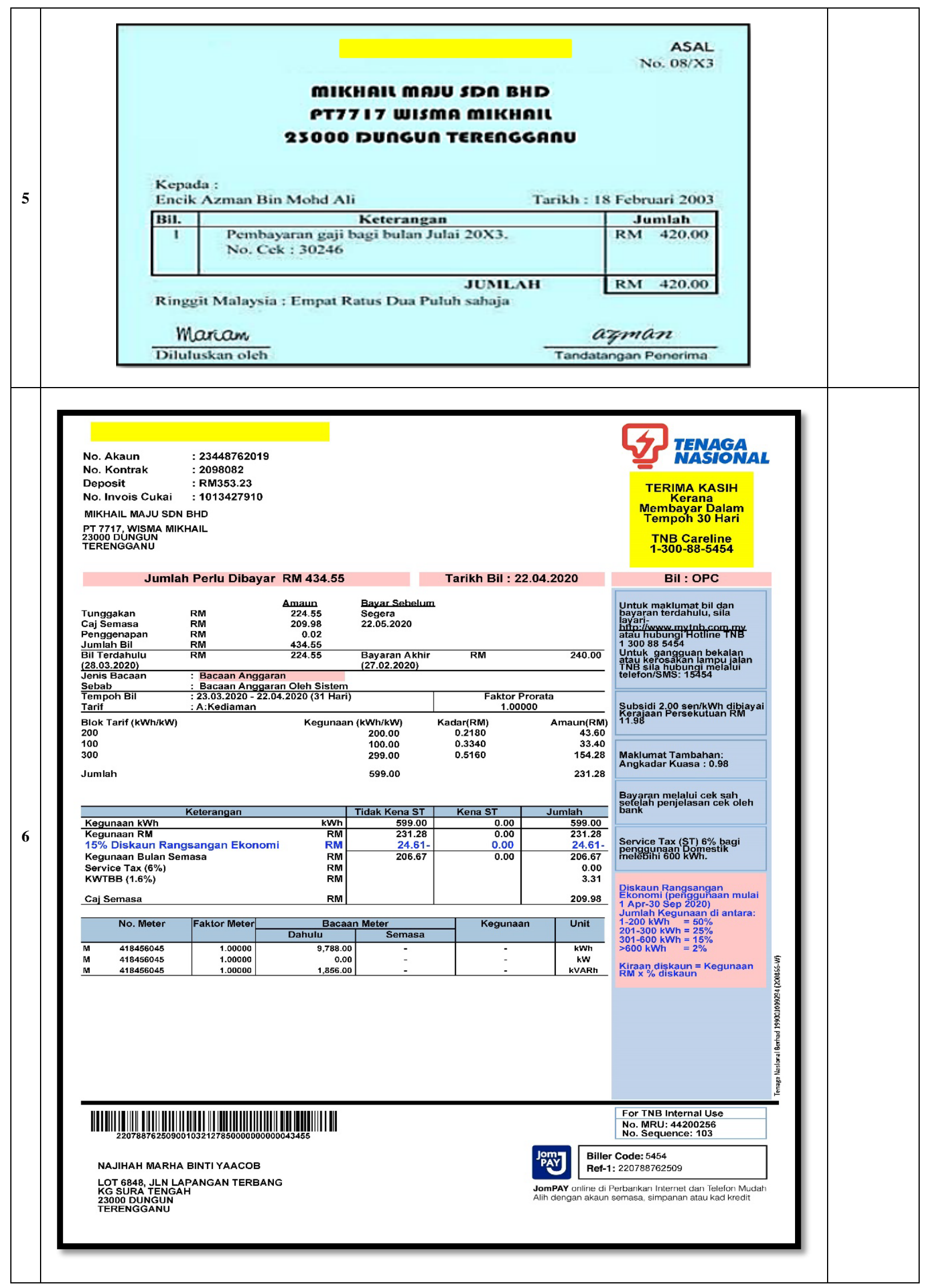




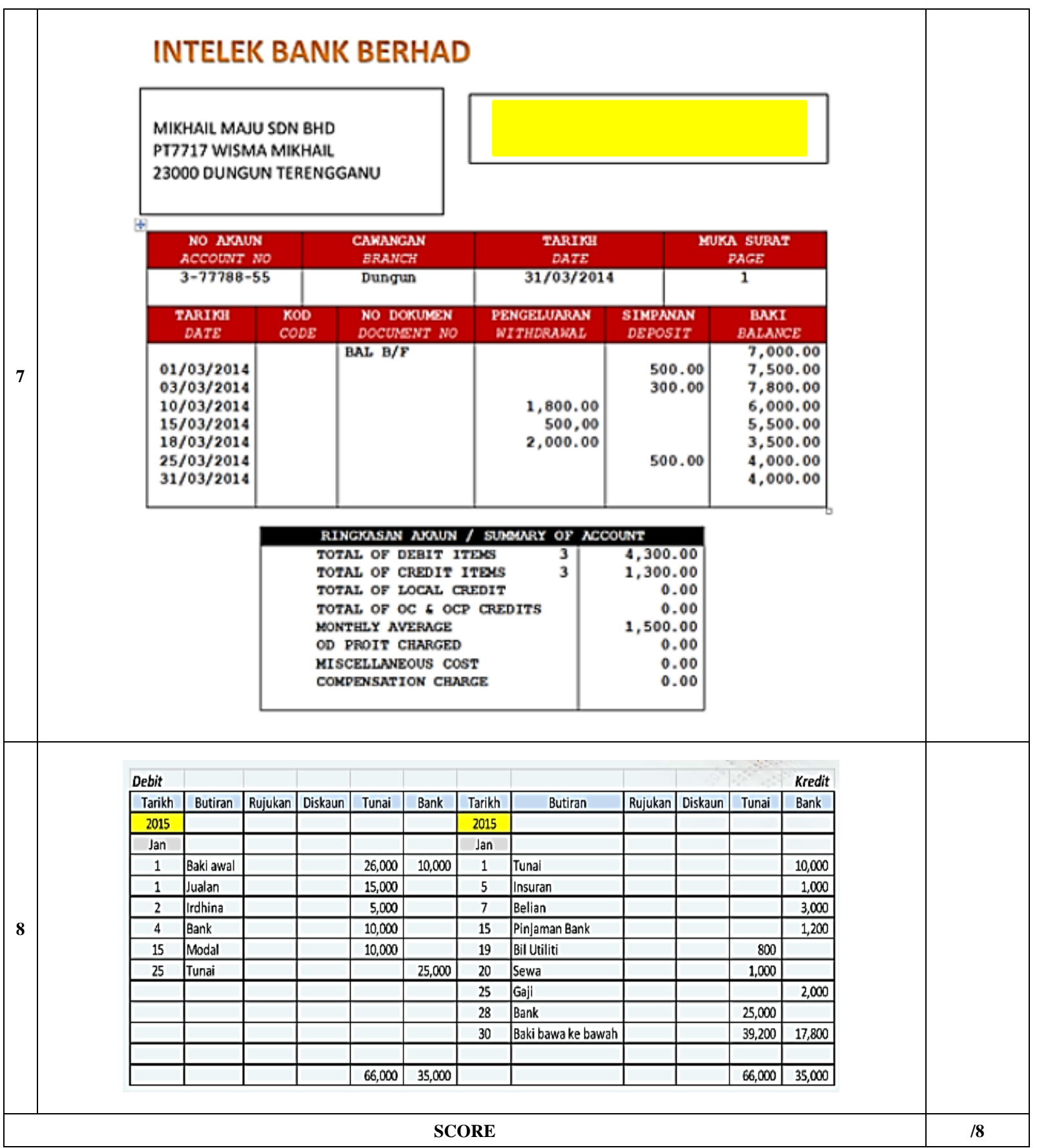




\section{REFERENCES}

[1] Code of Practice Programme Accreditation (COPPA). Online available from: https://www2.mqa.gov.my/qad/gari spanduan/COPIA/2019/Final\%20COPPA-DL\%202nd\%20 edition\%204.12.19.pdf

[2] W. J. McKeachie. McKeachie’s Teaching Tips: Strategies, Research, Theory for College and University Teachers, (11 ${ }^{\text {th }}$ ed.). Boston, MA, Houghton Mifflin, 2012.

[3] C. Beard, J. P. Wilson. Experiential Learning: A Handbook of Best Practices for Educators and Trainert, London, 2006.

[4] M. J. Austin, D. Z. Rust. Developing an experiential learning program: Milestones and Challenges, International Journal of Teaching and Learning in Higher Education, Vol. 27, No. 1, 143-153, 2015.

[5] E. Charles-Edwards, M. Bell, J. Corcoran. Integrating undergraduate fieldwork into the study of human mobility, Australian Geographer, Vol. 45, No.4, 505-519, 2014.

[6] M. Chavan. Higher education students' attitudes towards experiential learning in international business, Journal of Teaching in International Business, Vol. 22, No. 2, 126-143, 2011.

[7] J. S. Coker, E. Heiser, L. Taylor, C. Book. Impacts of experiential learning depth and breadth on student outcomes, Journal of Experiential Education, Vol.40, No. 1, 5-23, 2017.

[8] P.H. Jensen. The application of Kolb's experiential learning theory in a first semester college accounting course, The University of Memphis, ProQuest Dissertations Publishing, 9542171, 1995.

[9] S. Sugahara, S. Dellaportas. Bringing active learning into the accounting classroom, Meditari Accountancy Research, Vol. 26, No. 4, 576-597, 2018.

[10] R. M. Cornell, C. B. Johnson, W. C. Schwartz Jr. Enhancing student experiential learning with structured interviews, Journal of Education for Business, Vol. 88, No. 3, 136-146, 2013.

[11] C. Walker. Experiential learning and the effects on student completion and academic success in a business course at a community college university, ProQuest Dissertations Publishing, 10846508, 2018.

[12] S. Dellaportas, T. Hassall. Experiential learning in accounting education: A prison visit, The British Accounting Review, Vol. 45, No.1, 24-36, 2013.

[13] J. M. Martin. The self-efficacy of low act-scoring students in an experiential learning environment, A Dissertation for Degree Doctor of Philosophy in Education, Capella University, 2018.

[14] E. Boulianne. Impact of accounting software utilization on students' knowledge acquisition: An important change in accounting education, Journal of Accounting \& Organizational Change, Vol.10, No. 1, 22-48, 2014.

[15] S. Lightweis. Bridging the gap between accounting students and the profession: A case study, Higher Education Studies, Vol.4, No. 5, 18-27, 2014.

[16] R. Ali, W.M.N. Wan Mohd Nori, I. Baharuddin. Accounting experiential learning firm (AELF): Learning accounting in an office setting, TEM Journal, Vol. 8, No.2, 686-691, 2019.

[17] S. L. Juergens. Experiential learning: How the utility of experiential learning within a MBA course enables transfer of learning Ambrose University, ProQuest Dissertations Publishing, 3535072, 2012. 